DOI: https://doi.org/10.34069/AI/2021.43.07.26

How to Cite:

Hromovenko, K., Minchenko, R., Sarybaieva, G., Batan, Y., \& Minchenko, D. (2021). Legal responsibility for vaccination against COVID-19 in Ukraine and other countries. Amazonia Investiga, 10(43), 264-271. https://doi.org/10.34069/AI/2021.43.07.26

\title{
Legal responsibility for vaccination against COVID-19 in Ukraine and other countries
}

\section{Юридична відповідальність щодо вакцинації проти COVID-19 в Україні та інших країнах}

Received: July 12, 2021

\section{Abstract}

This article analyzes the liability that may arise in case of refusal to receive a COVID-19 vaccine shot, as well as vaccination-related problems in Ukraine and worldwide. We focused on the international and Ukrainian situation regarding the COVID-19 vaccination process. We also considered the legal framework on this issue. The main task of the study was to determine whether there is a liability, including criminal liability, for refusing to receive the COVID-19 vaccine, the nuances, and the legal basis of this process. The research methodology includes general scientific and special scientific methods, such as systemic, structural, formal-legal, hermeneutic, and methods of analysis and synthesis. We found that COVID-19 vaccination is currently voluntary but not mandatory in Ukraine. At the same time, according to legal documents, vaccination against several diseases such as diphtheria, pertussis, measles, polio, tetanus, and tuberculosis is mandatory. Practically, this means that those who are subject to such preventive vaccinations may be subject to sanctions in the form of dismissal for refusing to vaccinate. Only a few foreign countries currently
Accepted: August 18, 2021

Written by:

Kostiantyn Hromovenko ${ }^{95}$ https://orcid.org/0000-0002-9466-8575

Raisa Minchenko ${ }^{96}$ https://orcid.org/0000-0003-0926-2341

Ganna Sarybaieva ${ }^{97}$ https://orcid.org/0000-0003-4492-956X

Yurii Batan ${ }^{98}$

https://orcid.org/0000-0003-4924-2054

Daria Minchenko ${ }^{99}$

https://orcid.org/0000-0002-3086-557X

\section{Анотація}

Стаття аналізує відповідальність, яка може виникнути у разі відмови від щеплення від COVID-19, а також проблеми, пов'язані 3 вакцинацією в Україні та у всьому світі. Ми зосередилися на ситуації в Україні та світі щодо процесу вакцинації проти COVID-19. Також, ми розглянули законодавчу базу 3 цього питання. Основним завданням дослідження було з'ясувати, чи існує відповідальність за відмову в отриманні вакцини від COVID-19, нюанси та правові підстави цього процесу. Методологія дослідження включає загальнонаукові та спеціальні наукові методи, такі як системний, структурний, формально-правовий, герменевтичний та методи аналізу та синтезу. Ми виявили, що вакцинація проти COVID-19 наразі є добровільною, але не є обов'язковою в Україні. Водночас, згідно 3 правовими документами, вакцинація проти кількох хвороб, таких як дифтерія, кашлюк, кір, поліомієліт, правця та туберкульоз, є обов'язковою. Практично це означає, що до тих, хто підлягає таким профілактичним щепленням, можуть бути застосовані санкції

\footnotetext{
95 Doctor of Legal Science, Associate Professor, Rector of the International Humanitarian University, Ukraine.

${ }^{96}$ Doctor of Legal Science, Professor, Honored Lawyer of Ukraine, Chairman of the NGO "Legal Dimension", Ukraine.

${ }^{97}$ Doctor of Legal Science, Associate Professor or the Department of Administrative and Financial Law, National University "Odesa Law Academy"(Odessa, Ukraine).

98 Assistant Professor of the department of constitutional law, National University "Odesa Law Academy"(Odessa, Ukraine).

${ }^{99} \mathrm{Ph} . \mathrm{D}$, Master of the Queen Mary University of London, Lawyer of JSC "Jurline", Ukraine.
} 


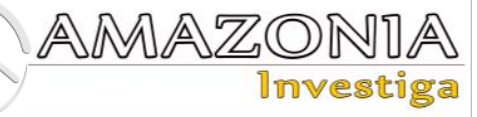

use mandatory COVID-19 vaccination for the entire adult population. More common is mandatory vaccination of certain categories of workers, including health workers, social workers, essential workers, civil servants, and others who are in close contact with people or whose health and well-being are of particular importance to national security.

Keywords: vaccination, COVID-19, legal responsibility, legal rights, Ukraine.

у вигляді звільнення за відмову від щеплення. Лише деякі іноземні країни наразі використовують обов'язкову вакцинацію проти COVID-19 для всього дорослого населення. Більш поширеним $є$ обов'язкова вакцинація певних категорій працівників, включаючи медичних працівників, соціальних працівників, працівників найважливіших службовців, державних службовців та інших, які перебувають у тісному контакті з людьми або чиє здоров'я та добробут мають особливе значення для національної безпеки.

Ключові слова: вакцинація, COVID-19, юридична відповідальність, законні права, Україна.

\section{Introduction}

The invention of COVID-19 vaccines is characterized by a phenomenal speed compared to the usual process of clinical trials and official approval of drugs for use (Kim, Dema, \& Reyes-Sandoval, 2020; Sharma, Sultan, Ding, \& Triggle, 2020). However, the vaccination process itself is different in different countries. This is influenced by various factors, in particular, trust in vaccines, the health care system, government institutions, the literacy of the population in science and medicine, etc. (Callaghan et al., 2020).

The right step is to support volunteers during the vaccination phase and their medical support. It is known, that different countries use methods to encourage people to be vaccinated against coronavirus (Steelfisher, Blendon, \& Caporello, 2021).

For example, they are provided with free movie tickets or public transport tickets. Nevertheless, there are dilemmas of a moral and ethical nature. For example, is a refusal to vaccinate a breach of moral duty to society? Is compulsory vaccination against COVID-19 an encroachment on personal liberty? Gradually, these topics are moving into the legal plane, which sets the task for the professional community to understand what responsibility can be provided for the various manifestations of offenses in the aspect of vaccination against COVID-19.

Thus, the authors of the article aimed to clarify the specifics of the application of legal liability in connection with the refusal of vaccination. An important aspect of the study is to establish the legality of liability for a person's refusal to vaccinate, because according to the general

approach contained, in particular in the decisions of the European Court of Human Rights, vaccination is a right, not an obligation. On the other hand, the current epidemic situation and the rapid spread of the Covid-19 virus require states to reconsider common approaches to vaccination and to introduce more stringent measures aimed at building "collective immunity".

\section{Theoretical Framework or Literature Review}

Seniuta $(2016,2018)$, in her publications, pointed to the need to revise the regulatory framework on the right of a person to consent to or refuse to receive medical care.

From the point of view of Sopilko \& Semchuk (2020), it is necessary to add COVID-19 to the list of diseases that require mandatory vaccination of workers and to provide for liability for refusing such a procedure.

Besides, Cranfield, Gorham, \& Waldman (2020) point out that a single approach to compulsory vaccination is unrealistic. Given the territorial, demographic, cultural, and educational differences between countries, employers in each of them must adapt to the transient vaccination requirements. In addition, public opinion is expected to change in this regard as we obtain new scientific empirical data on the effectiveness and consequences of vaccination.

Gur-Arie, Jamrozik, \& Kingori (2021) insist that the institutional challenges of healthcare professionals' trust in health care must be addressed before vaccination against COVID-19 is mandatory. 
Anja Krasser (2021) in her article «Compulsory Vaccination in a Fundamental Rights Perspective: Lessons from the ECtHR» analyses the problem of mandatory vaccination through the prism of the case law of the European Court of Human Rights (ECtHR). According to the author compulsory vaccination as well as the negative consequences arising from the duty constitute an interference with the protection of one's bodily integrity and self-determination. On the other hand, such interferences can be justified, provided that the benefit for the community outweighs the burden on the individual.

Pablo Octavio Cabral (2020) analyzes legal issues that are related to vaccination policies in the Argentine Republic. The author tries to find an approach to overcome the conflict that arises between the police power and individual freedoms in the face of public policies on health matters.

Jordão Horácio da Silva Lima (2021) analyzes the problems of mandatory vaccination from the perspective of the Federal Supreme Court of Brazil. The author of the article came to the conclusion that compulsory vaccination is a necessary tool to overcome the pandemic in Brazil and in the world as a whole. The Federal Supreme Court of Brazil has approved mandatory vaccination against covid-19, thus enabling the state to effectively address the challenges posed by the pandemic.

Javier Barceló Doménech (2020) touches upon the problems of vaccination against covid-19 in Spain. The author is also convinced that mass vaccination should take place, for which compulsory vaccination is necessary in one form or another.

\section{Methodology}

We used a systemic method to demonstrate the relationship between the health care regulatory framework in the context of vaccination. We demonstrated that the legal framework regarding vaccination is a rather diversified structure of interrelated elements, where part of the regulation of a particular issue can be found through the reference of one legal act to another. For example, this applies to orders of the Cabinet of Ministers of Ukraine, orders of the Ministry of Health, the law of Ukraine "On protection of the population from infectious diseases" (Law No. 1645-III, 2000), the Fundamentals of Ukrainian legislation on health care (Law No. 2801-XII, 1992).
The structural method was useful for demonstrating the structure of legal norms on vaccination. For example, Art. 12 ("Preventive vaccinations") of the Law of Ukraine "On protection of the population from infectious diseases", if considered as a structural unit, contains some elements regarding the subjects, the situation of its application, and the consequences of evading its implementation.

Formal-legal and hermeneutic methods were used to explain the content and essence of legal norms in the field of vaccination. For example, this applies to the Fundamentals of Ukrainian legislation on health care, the decisions of the European Court of Human Rights regarding vaccination.

Methods of analysis and synthesis are used in the main body of the text, as well as in the conclusions.

\section{Results and Discussion}

\section{What is the situation regarding compulsory} vaccination?

In Ukraine, vaccination began on February 24, 2021. It will take place in four stages. At the first stage, physicians working with COVID-19 patients, residents of nursing homes, and servicemen in the environmental protection zone were vaccinated. In the second stage, vaccinations are given to health workers, people aged 80 and older, and social workers. In the third stage, people aged $65+$, educators, security guards, and critical infrastructure will be vaccinated. At the fourth stage of vaccination, vaccinations will be given to people over 60 and people with chronic diseases. Currently, vaccination against coronavirus in Ukraine is voluntary. According to the head of the Ministry of Health of Ukraine, about $60 \%$ of the adult population of Ukraine is ready to be vaccinated against coronavirus, which means that the need for mandatory vaccination is not currently on the agenda (Word and Deed, 2021a). However, it is necessary to expand mass vaccination points and further adapt infrastructure to the worsening epidemic. As stated in the recommendations of the National Technical Group of Experts on Immunoprophylaxis (Position No. 30-06/2021-1, 2021b).

In addition to the issue of vaccination per se, the choice of an effective vaccine is also an important issue. Vaccines from reputable European and American manufacturers (Pfizer, Moderna etc.) are more trusted than vaccine 


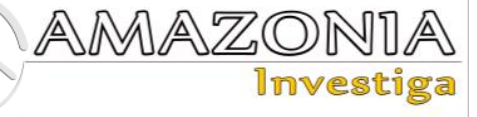

producted by Chinese or Indian manufacturers. At the same time, the mass production of the best-proven vaccines has not yet been established in the world. This is due to the reluctance of vaccine manufacturers to waive their intellectual property rights and related revenues. Indeed, the results of creative activity in any field - art, sports (Kharytonov et al., 2021) or pharmacology should belong to their creators. However, in the event of a pandemic, the traditional "commercial" approach to this issue must be changed.

According to open sources (Word and Deed, 2021b; Mind, 2021; Konstantinova, 2021) as of July 15, 2021, you can give examples of countries in which in one form or another there is a mandatory vaccination. For example, in the Russian capital, employers must provide at least $60 \%$ of vaccinated staff. The requirement applies to employees of catering, trade, beauty industry, household services, public transport, taxis, health care, education, art, housing, and communal services. Similar categories of workers in Kazakhstan were also required to be vaccinated or to undergo regular PCR testing. Mandatory vaccination has also been approved for at least 30 regions of the Russian Federation. Some of them have a formal obligation to vaccinate civil servants against COVID-19. Mandatory vaccination for all adults has been established in Turkmenistan and Tajikistan. In Indonesia, unvaccinated citizens face fines from February 2021. Employees of public and private organizations in Saudi Arabia are also required to be vaccinated. In the Indian state of Gujarat, unvaccinated students will not be allowed to take the exams, and workers who are in constant contact with people must be vaccinated. Medical and social workers in France are subject to compulsory vaccination. Restrictions are planned for unvaccinated citizens. Similar measures await the citizens of Greece. There, by September, doctors and staff of nursing homes are required to be vaccinated by September 2021. In Italy, unvaccinated doctors are planned to be fired without pay. Social workers in health and education in Latvia should be required to be vaccinated against coronavirus. From October 2021 in the UK, nursing home staff will also be required to vaccinate. In addition, mandatory vaccination of health workers in Hungary was announced on July 16. It began on August 1, 2021 (Kolomiets, 2021).

\section{What does the law say?}

The general rule for medical intervention, which is a form of preventive vaccinations, is that the patient's consent to such measures is mandatory. For example, Art. 43 of the Fundamentals of the legislation of Ukraine on health care establishes that before treatment, diagnosis, prevention, it is necessary to obtain the consent of the patient who was informed following Art. 39 of the Fundamentals, in which an adult patient is guaranteed the right to receive complete and accurate information about his health, acquaintance with medical documents about his person, as well as the risks and consequences that may entail medical intervention. In turn, his right correlates with the obligation of the medical worker to provide such information in an accessible form (Article 39.3 of the Fundamentals). Exceptions are cases when such information may significantly harm the patient's condition, course or results of treatment of the disease (Article 39.4 of the Fundamentals). If the medical intervention concerns a minor or an incapacitated person, the consent of the parents or guardian is required (Article 43.1 of the Fundamentals). Exceptions to the general rule of consent to medical intervention are cases where there are signs of a direct threat to the patient's life, and objectively there is no possibility to obtain consent from the patient or his parents / guardians (Article 43.3 of the Fundamentals). According to Art. 43.4 Basics, an able-bodied patient has the right to refuse treatment.

On the other hand, citizens of Ukraine are obliged to undergo preventive medical examinations and vaccinations in cases provided by law (paragraph "b" of Article 10 of the Fundamentals). In addition, persons who are carriers of infectious diseases dangerous to the population are excluded from work and other activities that may contribute to the spread of infectious diseases and are subject to medical supervision and treatment at the expense of the state with payment of social insurance benefits. Mandatory medical examinations, preventive vaccinations, medical and quarantine measures may be carried out in respect of certain particularly dangerous infectious diseases under the procedure established by the laws of Ukraine (Article 30.2 of the Fundamentals).

According to Art. 12 of the Law "On protection of the population from infectious diseases", preventive vaccinations against diphtheria, pertussis, measles, polio, tetanus, tuberculosis are mandatory and are included in the vaccination calendar.

Healthcare workers who carry out preventive vaccinations must be properly trained in their conduct and must provide objective information 
to vaccinated persons or their legal representatives on the effectiveness of preventive vaccinations and on possible post-vaccination complications. Prophylactic vaccinations are carried out after a medical examination of a person in the absence of appropriate medical contraindications. Prophylactic vaccinations are given to able-bodied adults with their consent after providing objective information about vaccinations, the consequences of refusing them, and possible post-vaccination complications. For persons who have not reached the age of fifteen or have been declared incapable of following the procedure established by law, preventive vaccinations are carried out with the consent of their objectively informed parents or other legal representatives. Persons between the ages of fifteen and eighteen or recognized by a court with limited legal capacity shall be given preventive vaccinations with their consent after providing objective information and with the consent of objectively informed parents or other legal representatives of these persons. If the person and (or) his / her legal representatives refuse the obligatory preventive vaccinations, the doctor has the right to take the appropriate written confirmation from them, and in case of refusal to give such confirmation - to certify it by an act in the presence of witnesses. Information on preventive vaccinations, post-vaccination complications and on the waiver of mandatory preventive vaccinations are subject to statistical accounting and are entered in the relevant medical documents. Medical contraindications, the procedure for preventive vaccinations, and registration of post-vaccination complications are established by the central executive body, which ensures the formation of state policy in the field of health care.

The explanation of the term "compulsory vaccinations" applies to epidemic vaccinations. An explanation for this can be found in the order of the Ministry of Health of Ukraine dated September 16, 2011 No. 595 "On the procedure for preventive vaccinations in Ukraine and quality control and circulation of medical immunobiological drugs." In addition, in the roadmap for the introduction of the vaccine against acute respiratory disease COVID-19 caused by coronavirus SARS-CoV-2, and mass vaccination in response to the pandemic COVID19 in Ukraine in 2021-2022, approved by the Order of the Ministry of Health of Ukraine No. 213 of February 9, 2021, it is stated that vaccination against coronavirus COVID-19 in Ukraine will be voluntary for all groups of the population and occupational groups. It also provides information on the results of mathematical simulations that indicate that $60 \%$ to $80 \%$ of the population should receive an effective vaccine to reduce the spread and mortality of COVID-19 coronavirus disease (Bartsch et al., 2020).

In Ukraine, since the beginning of the vaccination campaign against COVID-19, there is a significant percentage of health workers who refuse to be vaccinated for various reasons (Position No. 09-03/2021-1, 2021a).

A separate topic is the removal of the employee following Art. 46 of the Ukrainian Code of Labor Laws (Law No. 322-VIII, 1971) on the refusal of vaccination. In this case, it is not a matter of dismissal or disciplinary action, but the employee is temporarily suspended from performing his duties, and the employer - from providing this employee with work or creating conditions for its performance. Temporary suspension is a special precautionary measure to prevent negative consequences in the future. It does not entail dismissal, and the employee retains his job (Hryb, 2021). As to the Art. 23 of the Law "On protection of the population from infectious diseases", in case of impossibility to transfer to another job of a person who is a bacterium, and whose work is related to public services, which may lead to the spread of infectious diseases, such person is suspended from work, established by law, with the payment of benefits in connection with temporary disability. According to Art. 82 Labor Code (Law No. 322-VIII, 1971), Art. 9 of the Law "On Vacanions" the period of dismissal of the employee is not taken into account in the length of service, which gives the right to annual vacation. The employee at the same time, may appeal the employer's decision to temporarily suspend his / her duties in connection with the refusal to vaccinate in court in civil proceedings - according to the rules of the civil procedure legislation of Ukraine.

Administrative liability for offenses in the context of vaccination against COVID-19 may be provided under Art. 44-2 ("Violation of restrictions imposed on medical and pharmaceutical workers in the course of their professional activities"), Art. 44-3 ("Violation of the rules on quarantine of people") of the Code of Ukraine on Administrative Offenses.

The Criminal Code of Ukraine contains several rules that can be applied to various crimes in the context of the use of vaccines against COVID19. We are talking about the rules of Art. 141 ("Violation of the patient's rights"), 142 ("Illegal conduct of experiments on humans"), 184 


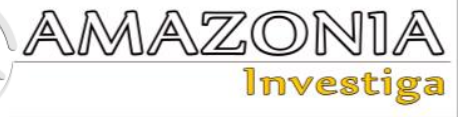

("Violation of the right to free medical care"), 321-1 ("Falsification of medicines or circulation of falsified medicines"), and 321- 2 ("Violation of the established procedure for pre-clinical studies, clinical trials and state registration of medicines") of the Criminal Code of Ukraine.

\section{Are there any rules that can be used to refuse?}

Article 29.2 of the Universal Declaration of Human Rights (United Nations, 1948) states that statutory restrictions on the rights and freedoms of the individual must be consistent with the rights of others, moral standards, the protection of public order, and the common good in a democratic society.

Theoretically, when refusing vaccination, individuals may refer to the legal grounds specified in Art. 1, 8, 9 of the Nuremberg Code of 1947; paragraph 16 of the Helsinki Declaration of the World Medical Association; Art. 6 UNESCO Declaration of 2005 on Bioethics and Human Rights; paragraphs 7.3.1., 7.3.2. PACE Resolution 2361 of 2021 "Vaccines against COVID-19: ethical, legal and practical considerations". In the context of vaccination, complainants to the ECtHR often refer to Art. 2, 3, 8, 10 ECHR.

Under Part 2 of Art. 19 of the Constitution of Ukraine, public authorities and local governments, their officials are obliged to act only on the basis, within the powers and in the manner prescribed by the Constitution and laws of Ukraine.

According to Art. 43 of the Constitution of Ukraine, everyone has the right to work, which includes the opportunity to earn a living by work, which he freely chooses or which he freely agrees. Citizens are guaranteed protection from illegal dismissal. The right to timely remuneration for work is protected by law.

\section{So what are the prospects for compulsory vaccination?}

Regarding the legal practice of compulsory vaccination in the world, the following can be noted. The European Court of Human Rights (ECtHR) in April 2021 (Vavřička and Others v the Czech Republic) recognized compulsory vaccination of children in the Czech Republic as not violating private rights and freedoms (ECHR: Ukrainian Aspect, 2021; Konstantinova, 2021). Diseases such as diphtheria, pertussis, tetanus, polio, hepatitis B, measles, rubella are listed in Czech legislation as subject to mandatory preventive vaccination. Failure to state a valid reason for refusing to vaccinate, for example, if it is incompatible with the state of health, carries the risk of serious complications, etc., may result in a fine. Kindergartens do not accept children without mandatory vaccinations unless it is explained by health indications. Accordingly, the applicants to the ECtHR complained of a violation of their right to respect for private and family life (Article 8 of the European Convention on Human Rights), freedom of thought, conscience, and religion (Article 9), and the right to education (art. 2 of Protocol No. 1 to the ECHR) for refusing to vaccinate their child. The ECtHR dismissed the complaints. The motivating part of the decisions stated that such restrictions and intrusions into private life were justified from the point of view of public safety, caused by the need to protect public health, and were carried out in the best interests of the child. In addition, it was outlined that states should put the best interests of the child in the formulation of appropriate policies, and in cases where immunization of the population does not meet public health goals, may introduce mandatory vaccination measures to build collective immunity and protect the population, which for one reason or another can not be vaccinated.

However, countries seeking compulsory vaccination against COVID-19 are unlikely to use this ECtHR practice, as it concerns an already established mechanism for immunizing the population (in this case, children attending kindergarten) against well-studied diseases. In addition, vaccination against them has been qualitatively studied, and complete empirical data on its safety are available. In addition, the practice of such restrictions has existed in democracies and before, for example, in the United States, Canada, Australia (Ministry of Health, 2018).

As stated in ECHR: Ukrainian Aspect (2021), it is possible that derogations from the right to voluntary vaccination will apply when vaccination is carried out as part of a routine immunization against a well-studied disease, and, in addition, is an effective and safe vaccine. Another factor is the unconditional nature of the measures taken for the benefit of the public good, which is a debatable category from a philosophical point of view, because there is a problem between public and private interests, plus a possible appeal to the category of goods, the relationship between public and private from them, but in this aspect the court decision which will be based on legal principles and will proceed from objective criteria of morbidity and course of 
the epidemic in the territory of the concrete country, is capable to define to a sufficient extent, whether obligatory vaccination promotes the public good.

\section{Conclusions}

In Ukraine, vaccination against COVID-19 is voluntary, but not mandatory. Instead, compulsory vaccination is prescribed in legislation on diseases such as diphtheria, pertussis, measles, polio, tetanus, and tuberculosis. In addition, vaccination against COVID-19 may be mandatory for particular categories of workers whose activities involve close contact with people. At present, the refusal to vaccinate certain categories of occupations and positions may be grounds for dismissal, but not for dismissal. Refusal of vaccination does not prohibit the transition to teleworking. The period of dismissal of an employee is not taken into account in the length of service, which gives the right to annual leave. The application of administrative and criminal liability for refusing to vaccinate against COVID-19 is not explicitly provided by law, but the relevant codes contain rules that may find their use in the context of vaccination. At the same time, the experience of some countries shows that refusing to vaccinate with COVID-19 can lead to fines, and mandatory vaccination of certain categories of citizens according to their type of activity is common among medical and social workers, as well as civil servants.

\section{Bibliographic references}

Bartsch, S. et al. (2020). Vaccine Efficacy Needed for a COVID-19 Coronavirus Vaccine to Prevent or Stop an Epidemic as the Sole Intervention. American Journal of Preventive Medicine, 59(4), 493-503. Recovered from https://doi.org/10.1016/j.amepre.2020.06.011.

Cabral, P.O. (2020) Vacunación obligatoria en la República Argentina como política pública de salud. REDEA. Derechos en Accion, 5(17), 659-685.

https://redib.org/Record/oai_articulo3012777-

vacunaci\%C3\%B3n-obligatoria-en-la-

rep $\% \mathrm{C} 3 \%$ BAblica-argentina-como-

pol\%C3\%ADtica-p\%C3\%BAblica-de-salud.

Callaghan, T. et al. (August 5, 2020). Correlates and disparities of COVID-19 vaccine hesitancy. Recovered from https://ssrn.com/abstract=3667971.

Cranfield, T., Gorham, J., \& Waldman, D. (December 14, 2020). Mandatory COVID-19 Vaccination - the International Employment Landscape. Legal Update. Recovered from https://www.seyfarth.com/newsinsights/mandatory-covid-19-vaccination-theinternational-employment-landscape.html.

da Silva Lima, J.H. (2021) A vacinação obrigatória na perspectiva do Supremo Tribunal Federal. Cadernos Ibero-Americanos de Direito Sanitário, 10(1), 233-247. https://www.cadernos.prodisa.fiocruz.br/index.p $\mathrm{hp} /$ cadernos/article/view/762/799.

Doménech, J. B. (2020). Régimen jurídico de las vacunas en España: Reflexiones ante la situación creada por el Coronavirus. Actualidad Jurídica Iberoamericana, 12 , 118-125. http://www.revista-aji.com/wp-

content/uploads/2020/05/12._Javier_Barcel\%C3 \%B3_pp._118-125.pdf.

ECHR: Ukrainian Aspect. (July 26, 2021). Vaccination against COVID-19: Legal basis for refusal and protection against further discrimination. Recovered from https://www.echr.com.ua/vakcinaciya-vidcovid-19-pravove-ob\%D2\%91runtuvannyavidmovi-i-zaxist-vid-podalsho\%D1\%97diskriminaci\%D1\%97/

Gur-Arie, R., Jamrozik, E., \& Kingori, P. (2021). No jab, no job? Ethical issues in mandatory COVID-19 vaccination of healthcare personnel. BMJ Global Health, 6(2), e004877. Recovered from

https://gh.bmj.com/content/bmjgh/6/2/e004877.f ull.pdf.

Hryb, V. (August 11, 2021). Refusal of vaccination and non-admission to work. Recovered from Protocolo, https://protocol.ua/ua/vidmova_vid_vaktsinatsii _i_nedopusk_do_roboti/.

Kharytonov, E., Kharytonova, O., Tkalych, M., Bolokan, I., Samilo, H., \& Tolmachevska, Y. (2021). Intellectual property law in the field of sports: specifics of manifestations and features of legal regulation. Cuestiones Políticas, 39(69), 530-546.

https://doi.org/10.46398/cuestpol.3969.33

Kim, Y.C., Dema, B. \& Reyes-Sandoval, A. (2020). COVID-19 Vaccines: Breaking Record Times to First-in-Human Trials. NPJ Vaccines, 5, 34. Recovered from https://doi.org/10.1038/s41541-020-0188-3.

Kolomiets, V. (August 15, 2021). Hungarian authorities are introducing compulsory vaccination against COVID-19 for health workers. Hromadske International, Recovered from https://hromadske.ua/posts/vladaugorshina-vvodit-obovyazkovu-vakcinaciyuproti-covid-19-dlya-medpracivnikiv.

Konstantinova, N. (August 3, 2021). Does the introduction of restrictions on the unvaccinated violate human rights? Radio Liberty. Recovered from https://www.radiosvoboda.org/a/chy- 


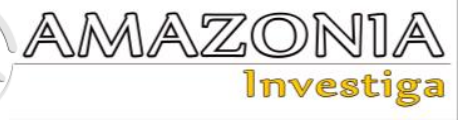

porushuyut-prava-ludyny-obmezhennya-dlanevaksynovanyh/31391717.html.

Krasser A. (June 3, 2021). Compulsory Vaccination in a Fundamental Rights Perspective: Lessons from the ECtHR. Vienna Journal on International Constitutional Law, $15(2)$, 207-233. https://www.degruyter.com/document/doi/10.15 15/icl-2021-0010/html.

Law No. 1645-III, On protection of the population against infectious diseases. Bulletin of the Verkhovna Rada of Ukraine, Kyiv, Ukraine, April 6, 2000. Recovered from https://zakon.rada.gov.ua/laws/show/1645-

14\#Text.

Law No. 2801-XII, Fundamentals of Ukrainian legislation on health care. Bulletin of the Verkhovna Rada of Ukraine, Kyiv, Ukraine, November 19, 1992. Recovered from https://zakon.rada.gov.ua/laws/show/2801-

12\#Text.

Law No. 322-VIII, Labor Code of Ukraine. Bulletin of the Verkhovna Rada of Ukraine, Kyiv, Ukraine, December 10, 1971. Recovered from https://zakon.rada.gov.ua/laws/show/32208/conv\#n17.

Mind. (June 29, 2021). Countries of the world where the authorities have introduced compulsory vaccination. Recovered from https://mind.ua/news/20227972-krayini-svitu-vyakih-vlada-zaprovadila-obovyazkovu-

vakcinaciyu.

Ministry of Health. (January 24, 2018). How vaccination issues are regulated in different countries of the world. Recovered from https://moz.gov.ua/article/health/jak-reguljujutpitannja-vakcinacii-u-riznih-krainah-svitu.

Order No. 213, On amendments to the Roadmap for the introduction of the vaccine against acute respiratory disease COVID-19 caused by coronavirus SARS-CoV-2, and mass vaccination in response to the pandemic of coronavirus disease COVID-19 in Ukraine in 2021-2022. Bulletin of the Verkhovna Rada of Ukraine, Kyiv, Ukraine, February 9, 2021. Recovered from

https://zakon.rada.gov.ua/rada/show/v021328221\#Text.

Order No. 595, On the procedure for preventive vaccinations in Ukraine and quality control and circulation of medical immunobiological drugs. Bulletin of the Verkhovna Rada of Ukraine, Kyiv, Ukraine, September 16, 2011. Recovered from

https://zakon.rada.gov.ua/laws/show/z1159-

11\#Text.

Position No. 09-03/2021-1, according to the protocol decision of NTGEI dated March 9, 2021 No. 6. National Technical Group of Experts on Immunoprophylaxis (NTGEI), Kyiv, Ukraine, March 9, 2021a. Recovered from https://www.phc.org.ua/sites/default/files/users/ user90/2021.03.16_Pozytsia_NTGEI_09.03.202 1.pdf.

Position No. 30-06/2021-1, according to the protocol decision of NTGEI dated June 30, 2021, No. 11. National Technical Group of Experts on Immunoprophylaxis (NTGEI), Kyiv, Ukraine, June 30, 2021b. Recovered from https://phc.org.ua/sites/default/files/users/user90 /2021.07.09_Pozytsia_NTGEI_30.06.2021.pdf.

Seniuta, I. (2016). The right to consent and the right to refuse medical care: features and limits of implementation. Entrepreneurship, Economy and Law, 10, 15-19. Recovered from https://bit.ly/3y4uS6x.

Seniuta, I. (2018). Balancing the interests of individual health and public health. Public Health: Problems and Development Priorities, 191-193. Ostroh: Ostroh Academy. Recovered from https://bit.ly/3mvOe2v.

Sharma, O., Sultan, A.A., Ding, H., \& Triggle, C.R. (2020). A Review of the Progress and Challenges of Developing a Vaccine for COVID19. Frontiers in Immunology, 11, 2413. Recovered from https://doi.org/10.3389/fimmu.2020.585354.

Sopilko, I., \& Semchuk, N. (2020). On some issues of compulsory vaccination: a historical aspect. Ukrainian Scientific Medical Youth Journal, 3(118), 67-68. Recovered from https://bit.ly/37UGHBF.

Steelfisher, G.K., Blendon, R.J., \& Caporello, H. (2021). An uncertain public - encouraging acceptance of COVID-19 vaccines. New England Journal of Medicine, 384(16), 14831487. DOI: 10.1056/NEJMp2100351.

Word and Deed. (July 15, 2021b). Which countries have introduced mandatory coronavirus vaccination. Recovered from https://www.slovoidilo.ua/2021/07/15/infografi $\mathrm{ka} / \mathrm{svit} /$ yaki-krayiny-zaprovadyly-obovyazkovuvakcynacziyu-koronavirusu.

Word and Deed. (July 15, 2021a). Lyashko told whether vaccination against COVID-19 will be mandatory in Ukraine. Recovered from https://www.slovoidilo.ua/2021/07/15/novyna/s uspilstvo/lyashko-rozpoviv-chy-bude-ukrayiniobovyazkova-vakcynacziya-covid-19.

United Nations. (1948). Universal Declaration of Human Rights. Recovered from https://zakon.rada.gov.ua/laws/show/995_015\#T ext. 